\title{
Allele frequencies of the third component of complement (C3) in MS patients
}

\author{
D E Bulman, H Armstrong, G C Ebers
}

\begin{abstract}
No difference was found in the allele frequency of C3 (third component of complement) in 129 multiple sclerosis (MS) patients compared with both 69 controls or with similar reported controls from the published literature. An association cannot be confirmed between C3 and MS.
\end{abstract}

Extensive genetic polymorphism of the third component of complement (C3) has been found in humans. ${ }^{12}$ Gene products are recognised by their relative electrophoretic mobilities in prolonged agarose-gel electrophoresis. ${ }^{1}$ The use of calcium in the electrophoresis buffer in appropriate concentrations has been shown to cause $\mathrm{C} 3$ to migrate slower than transferrin and usually more slowly than beta lipoprotein. ${ }^{3}$ The allotypes, which are inherited in an autosomal codominant manner, appear to differ in net surface charge at $\mathrm{pH} 8 \cdot 6$, but show no difference in complement activity, molecular size or ability to bind calcium. $^{1}$

Rheumatoid factor positive rheumatoid arthritis, ${ }^{4}$ atherosclerotic vascular disease ${ }^{5}$ and hepatitis ${ }^{4}$ are associated with the fast $(F)$ allele of C3. More recently Jans and Sorensen ${ }^{6}$ reported that a group of 60 multiple sclerosis (MS) patients were found to contain a significantly higher frequency of the fast allele than did 1066 controls. Because of accessibility to a large number of MS patients, we felt that a definitive answer could be obtained on the possible association between MS and C3 polymorphisms.

\section{Methods}

Diagnosis

Department of Clinical Neurological Sciences, The University of Western Ontario, London, Ontario, Canada D E Bulman H Armstrong G C Ebers

Correspondence to: Dr Ebers, Department of Clinical Neurological Sciences, University Hospital, PO Box 5339 London, Ontario, Canad N6A 5A5

Received 19 July 1990 and in revised form 19 November 1990 Accepted 3 December 1990 probable $M^{8}$ were included in this study. All of the patients in this study were selected at random from the MS clinic in London, Ontario. ${ }^{9}$ The control subjects were white, over the age of twenty five and had negative neurological histories. No participants in this study were related.

The ratio of males to females in the MS patient group was $1: 1 \cdot 8$, which is the same ratio observed for the entire clinic population of 1400 . The ratio of males to females in the

Serum and plasma samples were collected and frozen $\left(-70^{\circ} \mathrm{C}\right)$ within three hours of collection from neurologically normal individuals and MS patients who were members of the MS clinic. A commercial preparation of the third component of human complement (C3) (Cedarlane, Canada) at a final concentration of $0.4 \mathrm{mg} / \mathrm{ml}$ was used as the positive control.

Typing for the third component of complement was performed by agarose gel electrophoresis as described elsewhere. ${ }^{1}$ The bridge buffer was barbital buffer of $\mathrm{pH} 8.6$ and ionic strength of 0.05 , containing $0.0018 \mathrm{M}$ calcium lactate. Samples were thawed immediately before analysis. Gels were run at a constant voltage of $20 \mathrm{~V} / \mathrm{cm}$ for 3.5 hours at $4^{\circ} \mathrm{C}$, fixed in a $30 \%$ methanol, $20 \%$ acetic acid, stained with Coomassie Blue and destained in $30 \%$ methanol, $20 \%$ acetic acid. The position of $\mathrm{C} 3$ polymorphism was verified by an indirect immunoperoxidase overlay assay.

Comparison of the allele frequencies of MS patients to those of the controls was performed using a $2 \times 2$ contingency Chi square. ${ }^{10}$ The expected phenotype frequencies were calculated by applying the Hardy-Weinberg distribution $\left(a^{2}+2 a b+b^{2}=1\right)$ to the sum of the cases and controls. Odds ratio with $95 \%$ confidence intervals were calculated for the three phenotypes in cases versus controls.

\section{Results}

A total of 200 individuals were typed for C3 alleles, of whom two (one member of the control group and one of the MS patients) had an uncommon allele; subsequently these samples were not included in the study. The results of the typing are shown in table 1. The frequency of $\mathrm{C}^{\mathrm{F}}$ allele was $0 \cdot 1957$ and $0 \cdot 2210$, while the frequency of $\mathrm{C}^{\mathrm{S}}$ allele was 0.8043 and 0.7790 in the control and MS populations respectively. The distribution of the three common phenotypes (SS, FS, FF) within the control group was 1:1.

Table 1 Distribution of alleles of the third component of complement (C3) in MS patients ( $n=129)$ and normal controls $(n=69)$

\begin{tabular}{llll}
\hline $\begin{array}{l}\text { C3 } \\
\text { Phenotype }\end{array}$ & $\begin{array}{l}\text { Normal } \\
\text { controls }\end{array}$ & $\begin{array}{l}\text { MS } \\
\text { patients }\end{array}$ & Total \\
\hline SS & $46(42 \cdot 85)^{1}$ & $76(80 \cdot 10)$ & $122(122 \cdot 95)$ \\
FS & $19(23 \cdot 05)$ & $49(43 \cdot 10)$ & $68(66 \cdot 15)$ \\
FF & $4(3 \cdot 10)$ & $4(5 \cdot 80)$ & $8(8 \cdot 90)$ \\
Total & 69 & 129 & 198
\end{tabular}

'Expected values, given in brackets, were determined using Hardy-Weinberg distribution as applied to the total phenotype frequency. 
Table 2 Odds ratios with $95 \%$ confidence intervals for $S S, F S$ and FF phenotypes in MS patients $(n=129)$ and normal controls $(n=69)$

\begin{tabular}{lccll}
\hline Allele & Cases & Controls & OR & $95 \% C I$ \\
\hline SS & $76 / 129$ & $46 / 69$ & 0.717 & $(0.279$ to 1.155$)$ \\
FS & $49 / 129$ & $19 / 69$ & 1.612 & $(0.586$ to 2.638$)$ \\
FF & $4 / 129$ & $4 / 69$ & 0.520 & $(0.217$ to 1.546$)$ \\
\hline
\end{tabular}

control group compared with the MS patients was not significantly different (Chi square $=$ $2.782 ; 2$ df; $0.10<P<0.25$ ). Assuming that the C3 system is in a Hardy-Weinberg equilibrium, good agreement was found between observed and expected values (Chi square $=0.150 ; 1 \mathrm{df} ; 0.50<\mathrm{P}<0.75$ ). The odds ratios with $95 \%$ confidence intervals for the three phenotypes in cases versus controls are shown in table 2 .

\section{Discussion}

Recent evidence supports an important role for genetic factors in MS susceptibility. ${ }^{11}$ Inheritance of susceptibility appears to be polygenic with good evidence that $M \mathrm{HC}^{12}$ and possibly $T$ cell region ${ }^{13}$ loci each contribute part of the overall susceptibility. A surprisingly large number of population associations have been described in MS. As yet, in no case has the relationship of these to pathogenesis been demonstrated. It is suspected that some associations reflect population stratification (Bulman DE, MS Thesis, University of Western Ontario, 1986) which is well illustrated for $\mathrm{Gm}$ allotypes. ${ }^{14}$

The results given in the tables suggest that there is no association between any C3 allele and MS. An earlier report, however, had suggested a modest association between MS and $C 3^{\mathrm{F}}{ }^{6}$ There are differences between these two studies in the size of the patient and control groups. Jans and Sorensen typed 60 patients and 1066 blood donors (controls). In this study 129 patients and 69 neurologically normal controls were typed and no difference in allele frequency was found. Similarly there was no difference between the MS patients in this study and the larger control group of Jans and Sorensen (Chi square $=5.416 ; p>0.05$ ). Finally, the allele frequencies in the London, Ontario MS population ( $100 \%$ white) of 0.7790 and 0.2210 for $C 3^{s}$ and $C 3^{F}$ respec- tively, are extremely close to the frequencies 0.77 and 0.22 reported for the white population. ${ }^{15}$ The reason for the discrepancy between the studies is unclear but it may be due to the smaller patient group of the earlier study or it may be due to ethnic variation within the control group. Because the gene frequency of $\mathrm{C} 3^{\mathrm{F}}$ is approximately $20 \%$, homozygotes for the fast allele of $\mathrm{C} 3$ would represent only $4 \%$ of the population, thus requiring a relatively large patient sample size for definitive results.

Our results suggest that there is no association between MS and any particular allele of C3. It is possible that the reported association reflects yet another population association secondary to differential MS patient and control stratification.

This work was supported by The Multiple Sclerosis Society of Canada.

1 Alper CA, Propp RP. Genetic polymorphism of the third component of complement (C3). J Clin Invest 1968; 47:2181-91.

2 Azen EA, Smithies O. Genetic polymorphism of $\mathrm{C}_{3}\left(\mathrm{~B}_{\mathrm{IC}}{ }^{-}\right.$ globulin) in human serum. Science 1968;62:905-7.

3 Laurell CB, Laurell S, Skoog N. Buffer composition in paper electrophoresis. Considerations on its influence, with special references to the interaction between small ions and proteins. Clin Chem 1956;2:99-111.

4 Farhud DD, Ananthakrishnan R, Walter H. Association between $\mathrm{C} 3$ phenotypes and various diseases. Humangenetik 1972;17:57-60.

5 Sorensen $\mathrm{H}$, Dissing J. Association between the $\mathrm{C3}^{\mathrm{F}}$ gene and atherosclerotic vascular disease. Human Heredity and atherosclerotic

6 Jans H, Sorensen H. C3 polymorphism and circulating immune complexes in patients with multiple sclerosis. Acta Neurol Scandinav 1980;62:237-43.

7 Schumacher GA, Beebe G, Kibler RF, et al. Problems of experimental trials of therapy in MS: Report by the panel on the evaluation of experimental trials of therapy in multiple sclerosis. Ann NY Acad Sci 1965;122:552-68.

8 Poser CM, Paty DW, Scheinberg L, et al. New diagnostic criteria for multiple sclerosis. Guidelines for research protocols. In: Poser CM, Paty DW, Scheinberg L, McDonald WI, Ebers GC, eds. The diagnosis of multiple sclerosis. New York, Thieme-Stratton, 1984.

9 Weinshenker BG, Bass B, Rice GPA, et al. The natural history of multiple sclerosis: a geographically based study. I clinical course and disability. Brain 1989;112:133-46.

$10 \mathrm{Zar}$ JH. Biostatistical analysis. Englewood Cliffes, NJ: Prentice-Hall, 1974.

11 Ebers GC, Bulman DE, Sadovnick AD, et al. A populationbased twin study in multiple sclerosis. New Engl J Med 1986;315:1638-42.

12 Ebers GC. The genetics of MS. Neurologic Clinics of North America. 1983;1:645-54.

13 Seboun E, Robinson MA, Doolittle TH, et al. A susceptibility locus for multiple sclerosis is linked to the $T$ cell receptor beta chain complex. Cell 1989;57(7):1095-100.

14 Steinberg AG, Cook CE. The distribution of human immunoglobulin allotypes. Oxford monographs on medical genetics. Oxford: Oxford University Press, 1981.

15 Alper CA, Rosen FS. Studies of a hypomorphic variant of human C3. J Clin Invest 1971;50:324-6. 